\title{
ACADEMIC COLLABORATIONS IN THE AMERICAS: SOME REFLECTIONS ON THE POLITICAL ECONOMY OF LEGAL KNOWLEDGE
}

\author{
COLABORAÇÕES ACADÊMICAS NAS AMÉRICAS: ALGUMAS REFLEXÕES \\ ACERCA DA ECONOMIA POLÍTICA DO CONHECIMENTO JURÍDICO
}

\section{COLABORACIONES ACADÉMICAS EN LAS AMÉRICAS: ALGUNAS REFLEXIONES ACERCA DE LA ECONOMÍA POLÍTICA DEL CONOCIMIENTO JURÍDICO}

\begin{abstract}
DANIEL BONILLA MALDONADO
Professor da faculdade de direito da Universidade dos Andes em Bogotá, Colômbia. Doutor e mestre em Direito pela Universidade de Yale, Estados Unidos, e o título de advogado na Universidade dos Andes. Bogotá, Colômbia. http://orcid.org/0000-0002-8303-6783 / dbonilla@uniandes.edu.co
\end{abstract}

Colin CRAWFord

Ocupante da cadeira Robert C. Cudd do direito ambiental na Universidade de Tulane, Estados Unidos, onde dirige os programas de desenvolvimento internacional. Professor na Faculdade Guanambi, Bahia. Mestre em História pela Universidade de Cambridge, Inglaterra. Pós-graduado na Universidade de Harvard, Estados Unidos. Nova Orleans,

Luisiana, Estados Unidos.

http://orcid.org/0000-0001-6996-3284 / colin.crawford@tulane.edu

\begin{abstract}
The article proceeds in three parts. The first, the articles' analytical heart, considers the political economy of legal knowledge. It describes briefly the free market of legal ideas and the colonial model for the production of legal knowledge. It illustrates how these two models work using examples from our "South-North Partnerships" (SNP), that is, our collaborative practices in the creation of legal thought as they play out in the legal academies of the global North and South. The second part is both descriptive and reflective, focusing on four different SNP examples that illustrate challenges in the creation of truly collaborative legal knowledge production processes. It identifies common challenges in these endeavors, from surmounting basic organizational issues such as language barriers to jostling with fundamentals like conflicting academic calendars. Most importantly, the second part indicates how the dynamics of the political economy of legal knowledge played out in the SNPs described. It also highlights possible ways to equalize these relationships and activities, with an end to creating SNPs focused on truly collaborative legal knowledge production. The third part offers conclusions and recommendations.
\end{abstract}

Keywords: Law Theory; Legal knowledge; International collaborations; Political Economy of Law.

\section{RESUMO}

0 artigo prossegue em três partes. A primeira, o coração analítico do artigo, considera a economia política do conhecimento jurídico. Descre brevemente o livre mercado de ideias legais e o modelo colonial para a produção do conhecimento jurídico. Ela ilustra como esses dois modelos funcionam usando exemplos de nossas "Parcerias SulNorte" (SNP), isto é, nossas práticas colaborativas na criação do pensamento jurídico como elas se desenvolvem nas academias jurídicas do Norte e Sul global. A segunda parte é descritiva e reflexiva as mesmo tempo, enfocando em quatro exemplos diferentes de SNPs que ilustram alguns desafios na criação de processos de produção de conhecimento legal verdadeiramente colaborativos. Ela identifica desafios comuns nestes esforços, de superar questões organizacionais básicas, tais como barreiras linguísticas, até contestar fundamentos como calendários acadêmicos incompatíveis. Mais importante ainda, a segunda parte indica como a dinâmica da economia política do conhecimento jurídico evoluiu nas SNPs descritas. Ela também destaca formas possíveis de equalizar essas relações e 
atividades, com o fim da criação de SNPs focadas na real produção colaborativa de conhecimento legal. A terceira parte apresenta conclusões e recomendações.

Palavras-chave: Teoria de direito; Conhecimento jurídico; Colaborações internacionais; Economia Política do Direito.

\section{RESUMEN}

El artículo prosigue en tres partes. La primera, el corazón analítico del artículo, considera la economía política del conocimiento jurídico. Describa brevemente el libre mercado de ideas legales y el modelo colonial para la producción del conocimiento jurídico. , Que ilustra cómo estos dos modelos funcionan usando ejemplos de nuestras "Alianzas SurNorte" (SNP), es decir, nuestras prácticas colaborativas en la creación del pensamiento jurídico como se desarrollan en las academias jurídicas del Norte y Sur global. La segunda parte es descriptiva y reflexiva al mismo tiempo, enfocando en cuatro ejemplos diferentes de SNP que ilustran algunos desafíos en la creación de procesos de producción de conocimiento legal verdaderamente colaborativos. Identifica desafíos comunes en estos esfuerzos, de superar cuestiones organizacionales básicas, tales como barreras lingüísticas, hasta cuestionar fundamentos como calendarios académicos incompatibles. Más importante aún, la segunda parte indica cómo la dinámica de la economía política del conocimiento jurídico evolucionó en las SNP descritas. También destaca formas posibles de equalizar esas relaciones y actividades, con el fin de la creación de SNPs enfocadas en la real producción colaborativa de conocimiento legal. La tercera parte presenta conclusiones y recomendaciones.

Palabras clave: Teoría de derecho; Conocimiento jurídico; Colaboraciones internacionales; Economía Política del Derecho.

\section{SUMMARY}

INTRODUCTION; 1 THE POLITICAL ECONOMY OF LEGAL KNOWLEDGE; 1.1 The Colonial Model of Legal Knowledge Production; 1.2 The Free Market Model of Legal Knowledge Production; 2 THE POLITICAL ECONOMY OF LEGAL KNOWLEDGE AND OUR SNPS; 2.1 SNP 1 - Central America and Caribbean Legal Pedagogy; 2.2 SNP 2 - US-Latin American Debate on the Social Function of Property; 2.3 SNP 3 Discussion of Urban Development, Law and Policy in the Americas; 2.4 SNP 4 - Moot Court in Latin America; 3 ANALYTICAL AND PRACTICAL LESSONS LEARNED; CONCLUSION; REFERENCES.

\section{INTRODUCTION}

Legal knowledge is a commodity, a product generated, exchanged and used in specific contexts and following certain rules; it is neither produced in a vacuum nor in a chaotic fashion. This set of rules and principles that shape the production of legal knowledge constitute the political economy of legal knowledge ${ }^{1}$ - rules that comprise the conditions of possibility for its generation, circulation and application. Thus, for example, the political economy of legal knowledge determines the worthy objects of study, which contexts for the production of it are most valuable and which ones less so, and which are the procedures for original legal knowledge production $^{2}$.

\footnotetext{
${ }^{1}$ Rubio F. and Baert P. (Eds.). 2012. The Politics of Knowledge.

2 This text, written in English for a Brazilian legal academic publication and for consumption by a largely Brazilian academic legal audience, is an ideal illustration of the challenges that we discuss below. Indeed,
} 
ISSN 1981-3694

(DOI): $10.5902 / 1981369427197$

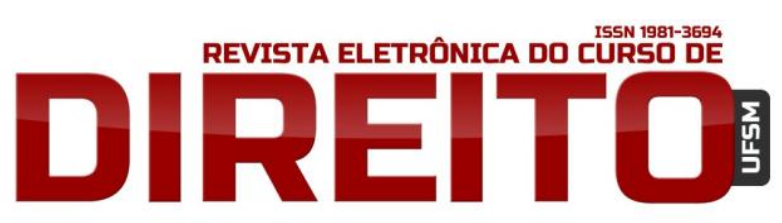

ACADEMIC COLLABORATIONS IN THE AMERICAS: SOME REFLECTIONS ON THE POLITICAL ECONOMY OF LEGAL KNOWLEDGE

DANIEL BONILLA MALDONADO COLIN CRAWFORD

This economy of legal knowledge is constituted by two models that co-exist in cognitive dissonance in the modern political and legal imagination ${ }^{3}$, namely the free market model of legal ideas and the colonial model of legal knowledge production. ${ }^{4}$ The first model represents the normative component of the political economy of legal knowledge; it offers the ideas that, it is believed, should guide the creation, exchange and use of legal knowledge. This model evaluates that type of knowledge according to norms like the utility that it has for the stability or prosperity of a political community, its explanatory or analytical value, or the extent to which the production occurred according to a meritocratic process. The second model, in contrast, provides the set of rules and principles that effectively determine the manner in which we typically respond to the specific commodity that is legal knowledge. This, the colonial model, is configured in terms of a set of oppositions, including mimesis/autopoiesis ${ }^{5}$, universal knowledge/local knowledge and languages appropriate for legal knowledge expression/languages inappropriate for its expression. These oppositions, in turn, determine the value that is given to legal products that are created and circulated within and among political communities ${ }^{6}$.

The political economy of legal knowledge is powerful not merely because of the rules and principles that constitute it. More importantly, it is powerful by virtue of the type of legal subject it constructs ${ }^{7}$. The two models imagine specific types of subjects of legal knowledge. These ways of imagining the legal subject that creates, shares and uses legal products contribute, in turn, to the creation and shaping of the identities of persons and communities. Once these ways of imagining the legal subject are internalized, individuals and collectivities use them to describe themselves. Implicitly or explicitly, the ways of imagining legal subjects are thus converted into the conceptual lenses through which persons and communities describe, examine and act towards legal knowledge. The force of the political economy of legal knowledge

in this the text is an example of the political economy that drives the production of legal knowledge today.

3 Bonilla, Daniel. 2015. “La economía política del conocimiento jurídico”, 26 Brazilian Journal of Empirical Legal Studies vol. 2, n. 1. p. 31.

${ }^{4}$ Bonilla, Daniel. 2015. "La economía política del conocimiento jurídico", 26 Brazilian Journal of Empirical Legal Studies vol. 2, n. 1. p. 32-54.

${ }^{5}$ These philosophical terms, both from the ancient Greek, translate as "imitation" or "reproduction" and "self-design so as to be self-sustaining", respectively. This conceptual opposition, mimesis/autopoiesis, describes the contents of the colonial legal systems as representations of the legal systems of the metropolis. The mimetic colony is therefore the space where the original knowledge emerging in the autopoietic metropolis is disseminated and applied locally.

6 Bonilla, Daniel. 2015. "La economía política del conocimiento jurídico", 26 Brazilian Journal of Empirical Legal Studies vol. 2, n. 1. p. 41-52.

7 Bonilla, Daniel. 2015. "La economía política del conocimiento jurídico", 26 Brazilian Journal of Empirical Legal Studies vol. 2, n. 1. p. 28. 
ISSN 1981-3694

(DOI): $10.5902 / 1981369427197$

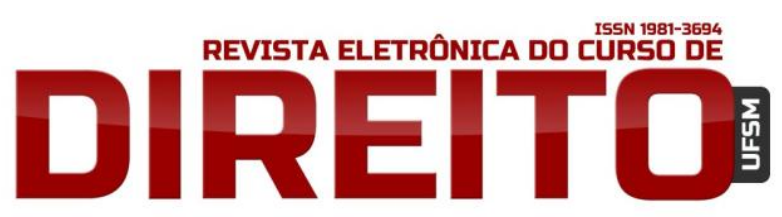

ACADEMIC COLLABORATIONS IN THE AMERICAS: SOME REFLECTIONS ON THE POLITICAL ECONOMY OF LEGAL KNOWLEDGE

DANIEL BONILLA MALDONADO COLIN CRAWFORD

is discernible as well in the constructions of time and space in which its imagined legal subjects move ${ }^{8}$. Each of the models offers a notion of history and a conceptual geography in which both the liberal and colonial models of legal knowledge are immersed.

However, the models that constitute the political economy of legal knowledge do not help merely to describe and analyze the macro-dynamics of the production, exchange and application of legal ideas and practices. They also may help to explain the micro-dynamics that constitute daily life in this social sphere. An examination of the political economy of legal knowledge thus can contribute to the understanding of routine practices that determine the ways in which we create, exchange and use legal knowledge. To that end, this article attempts to demonstrate how these collaborative practices are in fact characterized by a relation that typically involves a dominant global North and subordinate global South partner or partners. Thus, the article seeks to contribute to the creation of a model of the political economy of legal knowledge distinct from both the free market and colonial models of legal ideas.

Specifically, the article discusses collaborative projects realized by its authors for well over a decade as a way of exploring the reach and the limitations of the dominant models of the political economy of legal knowledge. In this, using four different cases or types of activities, it will document how the authors together sought to create critical, reciprocally beneficial and dynamic academic programming for Colombian, U.S. and other Latin American scholars and students. A central aim of this programming was to promote joint academic research. The activities have been varied and in some cases novel, including individual academic exchanges and visits, trainings for legal and other professionals, student learning opportunities in clinical and simulated human right court competitions, applied learning seminars across the Americas, and research projects and publications. In the present contribution, we seek to evaluate the success and challenges of this range of activities, which we refer to as "South-North Partnerships", or SNPs. ${ }^{9}$

The first part and analytical heart of the article presents the political economy of legal knowledge. In this section we describe briefly the free market of legal ideas and the colonial model for the production of legal knowledge and offer some alternative normative principles. To illustrate how these two models work we use some examples taken from our SNPs. The second

\footnotetext{
8 Bonilla, Daniel. 2015. "La economía política del conocimiento jurídico", 26 Brazilian Journal of Empirical Legal Studies vol. 2, n. 1. p. 29-30.

${ }^{9}$ Bonilla, Daniel. 2013b. Legal Clinics in the Global North and South: Between Equality and Subordination, 16 Yale Hum. Rts. \& Dev. L.J. 176.
} 
part builds upon this effort and is both descriptive and reflective. Although the authors have worked together on a variety of SNPs, for purposes of this analysis, the discussion will focus on four different types of SNP that illustrate the challenges posed for the creation of truly collaborative legal knowledge production processes. The third part, finally, offers some brief conclusions and recommendations.

\section{THE POLITICAL ECONOMY OF LEGAL KNOWLEDGE}

The political economy of legal knowledge is constituted by discourses and practices that determine how legal knowledge is produced, exchanged and used. These rules, principles and activities constitute the conceptual architecture that describes and articulates the normative horizons within which individuals produce, exchange and apply legal knowledge. This conceptual architecture $^{10}$ thus enables thought and action but also circumscribes them. As indicated above, the political economy of legal knowledge is constituted both by the colonial model of legal knowledge production and by the free market of legal ideas model.

\subsection{The Colonial Model of Legal Knowledge Production}

The colonial model creates two interdependent subjects: the metropolis subject ${ }^{11}$ and the colonial subject ${ }^{12}$. The existence of one depends upon the other. Their identities are determined by the place they inhabit and the race with which the model imagines them. The metropolis subject is identified with the Global North and imagined as white. The colonial subject is identified with the Global South and imagined as non-white. The metropolis subject is understood as an individual with the ability to create original legal knowledge, a true subject of legal knowledge and rights. By contrast, the colonial subject is a legal barbarian, a mere object of rights who only has the ability to reproduce and disseminate legal knowledge created elsewhere. The subject of the metropolis, therefore, has a legal history and is constituted by a narrative that gives meaning to his work and content to his identity. His is a historical narrative

\footnotetext{
${ }^{10}$ Kahn, Paul. 1999. The Cultural Study of Law.

${ }^{11}$ For the sense in which we use the word "metropolis" in opposition to "colonial", see, e.g., Jennifer Anne Boittin, Colonial Metropolis: The Urban Grounds of Anti-Imperialism and Feminism in Interwar Paris (University of Nebraska: Lincoln, 2015)

12 Bonilla, Daniel. 2015. "La economía política del conocimiento jurídico", 26 Brazilian Journal of Empirical Legal Studies vol. 2, n. 1. p. 39-54.
} 
ISSN 1981-3694

(DOI): $10.5902 / 1981369427197$

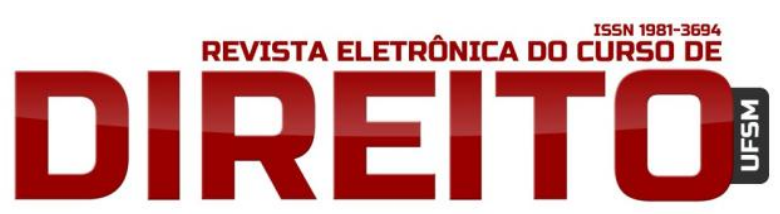

ACADEMIC COLLABORATIONS IN THE AMERICAS: SOME REFLECTIONS ON THE POLITICAL ECONOMY OF LEGAL KNOWLEDGE

DANIEL BONILLA MALDONADO COLIN CRAWFORD

that merits study. The colonial subject, in contrast, has no history or a history that is not worth telling or studying ${ }^{13}$.

The conceptual space that the colonial model imagines is also unidirectional. Exchanges of legal knowledge are presented as if they are following a single route: North to South. The diverse political communities of the world have similar needs. However, the legal products that might satisfy them, from the perspective of the colonial model, can only be created in the Global North. The Global North is the sole source of legal products worth exporting.

The concept of time that articulates the colonial model is linear but finite ${ }^{14}$. The metropolis is located at the end of history. It has overcome all the stages that lead to a strong, stable legal system and has transformed itself into a robust context for original legal knowledge creation. The lineal history of progress has no subsequent stage - beyond it there exists nothing. Time for the colony, by contrast, is inextricably linked to the metropolis's time - its future, its ideal. The past of the colony is something to be overcome; its present consisting of a constant effort to conquer one more stage in the path to the end of history.

The concepts of subject, space and time that articulate the colonial model of legal knowledge production presuppose four conceptual oppositions: mimesis/autopoiesis; local knowledge/universal knowledge; culture/law; and language suitable for legal knowledge/language unfit for legal knowledge ${ }^{15}$. The first conceptual opposition reaffirms the Global North as the locale for legal knowledge production suitable for global export, while the South is described as the space for the reproduction, dissemination and local application of the legal knowledge created by the Global North. The second conceptual opposition particularizes the legal knowledge produced in the Global South. This knowledge cannot be severed from the context in which it was created and is thus unsuitable for export. In contrast, legal knowledge of the Global North is held to possess universal character. It can travel freely across national frontiers; it can be applied anywhere in the world. The third conceptual opposition assumes that law can and should have an organic relationship with culture. Each culture should create its own law - one that reflects its ethos. The colonial model, thus, states that the Global North constitutes a robust context for legal knowledge production because it contains the cultural

\footnotetext{
${ }^{13}$ Morris, Rosalind and Spivak, Gayatri. 2010. Can the Subaltern Speak?

14 Bonilla, Daniel. 2015. "La economía política del conocimiento jurídico", 26 Brazilian Journal of Empirical Legal Studies vol. 2, n. 1. p. 41-43.

15 Bonilla, Daniel. 2015. "La economía política del conocimiento jurídico", 26 Brazilian Journal of Empirical Legal Studies vol. 2, n. 1. p. 44-49.
} 
ISSN 1981-3694

(DOI): $10.5902 / 1981369427197$

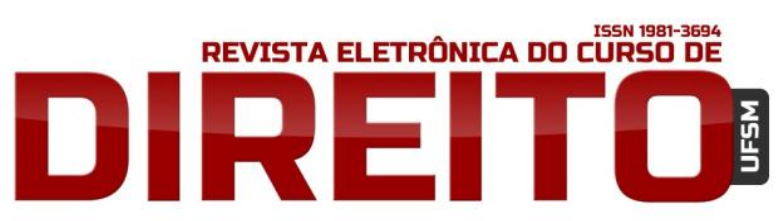

ACADEMIC COLLABORATIONS IN THE AMERICAS: SOME REFLECTIONS ON THE POLITICAL ECONOMY OF LEGAL KNOWLEDGE

DANIEL BONILLA MALDONADO COLIN CRAWFORD

prerequisites necessary to reach an elevated stage of legal development. In contrast, the cultures of the Global South are not understood to have the necessary characteristics to generate original legal knowledge and practice; they are still "primitive," pre-modern cultures.

The fourth conceptual opposition indicates that the dominant languages spoken in the Global North, and notably English, are particularly efficient vehicles to articulate high-quality, original legal knowledge. English, the dominant legal language of our time, is the default language for legal academic dialogues. Seminars and higher-quality international publications are (and it is believed should be) published in English, which is understood to be precise, clear, and direct, capable of articulating and containing legal ideas. Other languages, those more identified with the Global South, such as Spanish and Portuguese, are interpreted as defective vessels for the transport of legal ideas: dark, pompous, imprecise and ambiguous. Consequently, the legal scholar who speaks no English is doomed to the margins of legal discussions, condemned to remain in her provincial corner.

The colonial model and our SNPs are connected in various ways. Here, to illustrate how the model works, we would like to examine two of these links - those related to the conceptual opposition on language and the concept of subject. The language variable merits special consideration because it is often accompanied by judgments about the quality of legal knowledge production in different regions of the world. In our case, the U.S. and Latin American legal academies. In this way, the language variable - and the skepticism it can arouse if one is not agile in the dominant academic language - English - interacts with the third, cultural element mentioned above, to the detriment of the Latin American legal academic. This variable has cut across our SNPs.

Thus, for example, in the U.S. legal academy, to be a Colombian law professor who has English as a second language produces very different effects than to be a U.S. professor who visits Latin America and has Spanish as a second language. Colin Crawford, for example, has found that his status easily opens doors to do field work or organize an event with senior government officials in Latin America while Daniel Bonilla - with comparable qualifications and status - has not found it so easy to achieve similar objectives in the US. This is to note that, in our experience, in Latin America, the mere fact of being a US-based law professor, little matter the university of origin or the quality of academic production, carries a notable academic and social capital and allows the US professor to be treated as a serious actor. This is not necessarily so for a Colombian law professor in the US. Latin American academics must constantly prove themselves, in other words, bending over backwards to show that these negative or skeptical 
ISSN 1981-3694

(DOI): $10.5902 / 1981369427197$

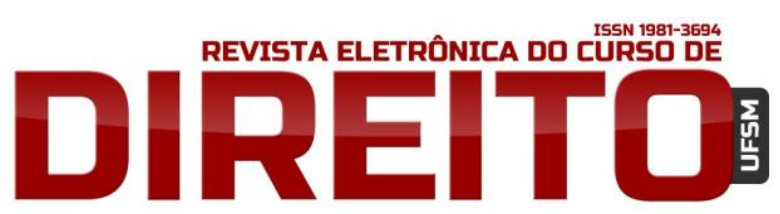

ACADEMIC COLLABORATIONS IN THE AMERICAS: SOME REFLECTIONS ON THE POLITICAL ECONOMY OF LEGAL KNOWLEDGE

Daniel Bonilla MALDONADo COLIN CRAWFORD

assumptions are wrong or do not apply to them. Indeed, what we say here is true of this text, which can be published in Brazil for a Brazilian academic legal audience. It is impossible to imagine the reverse being true: a Portuguese text published in the U.S. for a U.S. academic legal audience.

Language and membership in a particular academic community are also variables that have created challenges in the publication of collective works in the execution of some of the SNPs described below. Publishing a book or a special issue of a journal including contributions from Latin American academics is often met by Global North-based publishers or editorial staffs with inflexible demands. A common example we have encountered is an insistence that Latin American contributors translate sources for editors prior to publication in order to assure editors of the correctness of citation and argument, for example - and to do so at the cost of Latin American sources and contributors. By contrast, in our experience, the publishing and editorial reaction in Latin America is generally the opposite: to accept responsibility to work with Englishand other foreign-language sources as a cost of publication. This small fact illustrates the imbalances - and a central cost in financial and human terms - at the core of the political economy of legal knowledge production.

More generally, publishers in the Americas usually have different reactions to the work of U.S. and Latin American legal scholars. In our experience, U.S. publishers typically give manuscripts by Latin American law professors a cold or at best a lukewarm reception. In contrast, Latin American editorial houses react warmly to books or articles by U.S. legal academics. These views might change after the pieces are read and evaluated. The point is, however, that the publishers' a priori skeptical or less-than-welcoming attitudes create unjustified obstacles for Latin American legal scholars and, conversely, an unmerited flexibility with respect to the editorial courtesies accorded U.S. legal scholars.

Finally, it merits noting that we have consistently encountered three attitudes that put into operation the concept of subject that undergirds the colonial model. The first is the condescending attitude of some U.S. law professors regarding Latin American legal production and legal scholars. The attitude, usually implicit, is that Latin American researchers are ex ante categorized as a species of academic player who will disseminate - rather than initiate - legal knowledge. Conversely, the second attitude we have observed is a tendency on the part of some Latin American scholars to internalize and naturalize the rules and principles of the colonial model or to accept their "less-than-ness" as a price to be paid for participating in international networks and academic publications. However, the third attitude we have observed can also 
ISSN 1981-3694

(DOI): $10.5902 / 1981369427197$

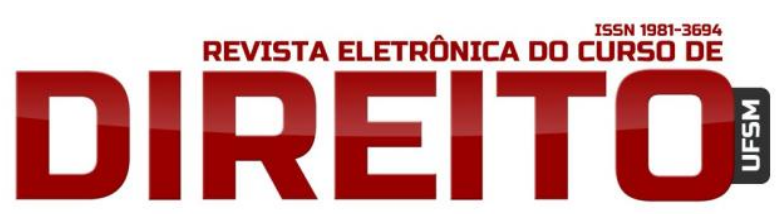

ACADEMIC COLLABORATIONS IN THE AMERICAS: SOME REFLECTIONS ON THE POLITICAL ECONOMY OF LEGAL KNOWLEDGE

DANIEL BONILLA MALDONADO COLIN CRAWFORD

work to the benefit of the colonial legal subject, who can be prized by virtue of what might be called his or her "exotic-ness". This is to say that the colonial model does not always disfavor Latin American legal scholars. Indeed, sometimes belonging to the Latin American legal academy opens spaces that are not typically available to many US law professors. Being an outsider to the Global North academic community, and to belong to an elite university in the Global South, can open channels of dialogue with institutions or individuals from the academic elites of the US and elsewhere in the Global North that are not always available to faculty at less elite institutions in the US. Thus, in some cases we have observed that a Latin American scholar can at the same time constitute the "other" and also be a member of the international academic elite.

\subsection{The Free Market Model of Legal Knowledge Production}

By contrast, the free market of legal ideas model posits an autonomous rational subject that has the ability to generate and exchange legal knowledge ${ }^{16}$. Since all individuals are potential creators of legal knowledge, in principle the model commits to equality. Under this model, the only legitimate differences between subjects are those that exist because of talent, discipline and hard work.

The model, therefore, is committed to a set of principles that intertwine with modern, enlightened values: truth, utility and meritocracy ${ }^{17}$. The most prized legal products and the most valuable knowledge subjects are those that capture the truth as completely and accurately as possible, whatever interpretation used to defend this elusive concept. The strongest subjects of knowledge and more robust legal products are those that allow the political community to fulfill its objectives, such as stability, justice and prosperity.

The concept of space created by the free market of legal ideas model is a globalized and multidirectional one ${ }^{18}$. The model's abstract subject of knowledge is able to create quality products anywhere in the world. The material conditions that characterize each space creating legal knowledge can enhance or limit these capabilities. However, these material conditions are also a function of individual and collective decisions, a result of the exercise of individual

\footnotetext{
16 Bonilla, Daniel. 2015. “La economía política del conocimiento jurídico”, 26 Brazilian Journal of Empirical Legal Studies vol. 2, n. 1. p. 32-33.

17 Bonilla, Daniel. 2015. "La economía política del conocimiento jurídico", 26 Brazilian Journal of Empirical Legal Studies vol. 2, n. 1. p. 35-39.

18 Bonilla, Daniel. 2015. "La economía política del conocimiento jurídico", 26 Brazilian Journal of Empirical Legal Studies vol. 2, n. 1. p. 34-35.
} 
ISSN 1981-3694

(DOI): $10.5902 / 1981369427197$

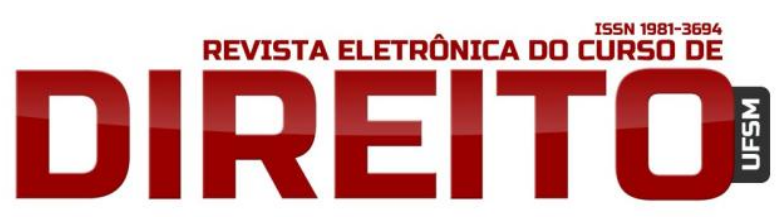

ACADEMIC COLLABORATIONS IN THE AMERICAS: SOME REFLECTIONS ON THE POLITICAL ECONOMY OF LEGAL KNOWLEDGE

DANIEL BONILLA MALDONADO COLIN CRAWFORD

autonomy. Similarly, the exchange of legal knowledge among abstract subjects (a subject that is defined only by its autonomy and rationality) can take any direction. The free market model does not predetermine the geographical orientation of trade; there is not, a priori, a single political community that monopolizes quality legal knowledge production.

The concept of time that constitutes the free market model of legal ideas is linear but infinite $^{19}$. In the free market of legal ideas, legal knowledge results from the interaction between reason and will ${ }^{20}$. The subject of legal knowledge is thus immersed in an infinite process of generating legal knowledge. Reason should guide individuals so that their legal products can get as close as possible to truth or can be as useful as possible for realizing the aims of the polity. However, reason is not the sole criteria for determining a legal product's value. The best legal product that reason produces cannot be considered valid and operationalized without the consent of those who have the power to create law in the political community, that is, without the consent of the sovereign. Of course, this will change over time depending on shifting political and social circumstances that require the creation of new legal products. Reason and will thus engage in a constant and infinite dialogue within the free-market of legal ideas model.

This existing model has in part conditioned the way in which we articulate and explain our joint SNPs. Our conversations and self-reflection processes make explicit that we sometimes describe our seminars, courses and publications as a consequence of two abstract subjects ${ }^{21}$ who work in a hard and disciplined way to achieve what we believe to be valuable political and epistemological aims. Yet these descriptions and analyses obscure variables like nationality, class or language that are central components of our identities as subjects of legal knowledge. The influence that the model has in our legal and political imagination also makes us conceive our academic products as a consequence of the agreements that we reach freely and guided by reason. These ideas, generally in an implicit and not always clearly organized way, often make us forget the existence of a geopolitics of legal knowledge.

Sometimes, for example, we conclude that the direction that our academic exchanges take, North-South or South-North, is in direct relation to the type of product that we want to create or with the material circumstances that limit the processes needed for its creation - for

\footnotetext{
19 Bonilla, Daniel. 2015. "La economía política del conocimiento jurídico", 26 Brazilian Journal of Empirical Legal Studies vol. 2, n. 1. p. 33-34.

${ }^{20}$ Kahn Paul. 1999. The Cultural Study of Law. p. 07-30.

${ }^{21}$ While of course neither of us is, in fact, an abstract [legal] subject but both have real identities and exist in real-world contexts.
} 
ISSN 1981-3694

(DOI): $10.5902 / 1981369427197$

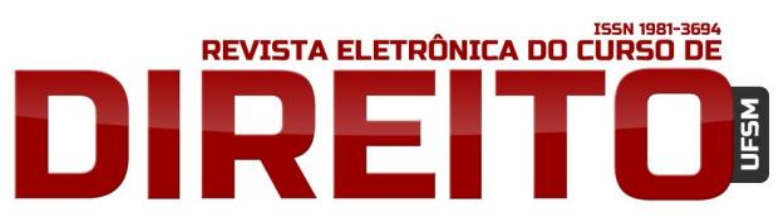

ACADEMIC COLLABORATIONS IN THE AMERICAS: SOME REFLECTIONS ON THE POLITICAL ECONOMY OF LEGAL KNOWLEDGE

DANIEL BONILLA MALDONADO COLIN CRAWFORD

example, available economic resources or the conditions imposed by sponsoring universities. Our legal products are thus interpreted as a consequence of our will and the scarcity of resources that influence any actor immersed in the global market of legal ideas. The free market of legal ideas model, therefore, obscures the role played by some variables that are directly related not with the capabilities that we have as abstract subjects of legal knowledge but with the specific variables that make us particular, flesh-and-bone legal academics.

We labored to move away from the descriptive and practical weaknesses of the two models of legal knowledge production discussed above, instead applying three principles to our joint SNPs. These principles were not clearly articulated and precise from the start, but evolved over time. First, we strove to be informed always by the principle of mutual recognition, taking into account our strengths and weaknesses as academics and as people, and also recognizing that we belong to different national legal communities. Moreover, we strove always to be conscious that we were operating in a global system of legal production that tended neither to endorse an equality principle in the abstract nor to acknowledge the inequality undergirding post-colonial relations. Second, we worked always to achieve consensus, building our SNPs by mutual agreement in all respects. At every stage of the execution of an SNP - coordination, realization and evaluation - we tried to keep our eyes on the importance of consensus between our project collaborators and us. Third and finally, prioritizing the academic objectives pursued by SNPs over purposes of personal and home institutional professional development.

In the following section we explain the links between these three principles and three specific SNPs that we have organized during the past years. We also show in more precise ways how the dominant political economy of legal knowledge has influenced our work.

\section{THE POLITICAL ECONOMY OF LEGAL KNOWLEDGE AND OUR SNPS}

The political economy of legal knowledge is constructed by the continuous interaction between structure and subject. Individual actors working inside this structure may view it uncritically, understanding it to be the "natural" option, internalizing the rules, principles and activities that constitute it. Thus, an individual can become the agent that reproduces this structure, consciously or not. Others may view the structure more critically and try to question or transform it, or act strategically within it, reaching for tools that permit them to resist, transform or substitute it. The SNPs realized together by the authors were shaped by the 
ISSN 1981-3694

(DOI): $10.5902 / 1981369427197$

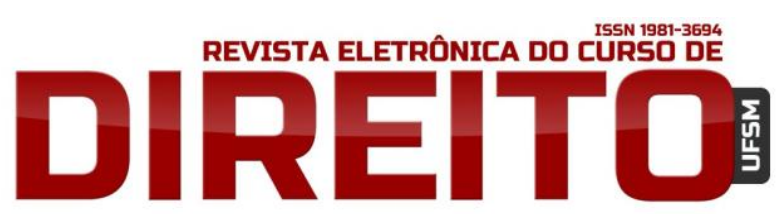

ACADEMIC COLLABORATIONS IN THE AMERICAS: SOME REFLECTIONS ON THE POLITICAL ECONOMY OF LEGAL KNOWLEDGE

DANIEL BONILLA MALDONADO COLIN CRAWFORD

political economy of legal knowledge. Further, the SNPs we describe below comprise initiatives partially or totally determined by a set of discourses and practices that are constituted by the two models that compose a part of our legal imagination, namely the free market of legal ideas model and the colonial model for the production of legal knowledge. The two models, implicitly or explicitly, determine the relevant aspects of the way in which we articulate and put into practice our projects and co-exist, in cognitive dissonance, within our juridical imagination. However, we work to create a distance from the way in which the models demand that we design and implement our academic initiatives as we sought - sometimes, but not always, explicitly - to construct an alternative narrative and practical path that can challenge the dominant models of legal knowledge production.

This section will detail some of our joint activities conducted over the past decade and in the course of this description offer some critical reflections on them based on the conceptual tools offered by the political economy of legal knowledge. Although some of the activities involved only one of the authors as an organizer, in nearly all of them both authors were participants and are thus positioned to explain and reflect upon the merits and concerns in all instances. In our descriptions and analyses below, we also offer details of the planning and preparation stages, and stress the structure and physical arrangements of the conferences. Such practical details can shape the nature of the interactions, including the inter-cultural and crossnational dynamics.

\subsection{SNP 1 - Central America and Caribbean Legal Pedagogy}

This first type of SNP was a U.S. government-funded effort to build capacity in legal pedagogy among Central American and Caribbean professionals. By definition, the SNP thus was one that implicitly placed high value on what US-trained academics would bring to their counterparts elsewhere. In this context, it was difficult to avoid the colonial model; what was being shared to improve local capacity was legal knowledge largely generated by and used in the Global North. As a result, the free market model was even absent for the most part. The emphasis was clearly on replicating a historical pattern of Global North-to-Global South knowledge transfer. As such, we were required to deliver classes and moderate discussions aimed to produce law and policy teaching materials useful and appropriate for Central American and Caribbean law classrooms. The participants were faculty and researchers from universities in 
ISSN 1981-3694

(DOI): $10.5902 / 1981369427197$

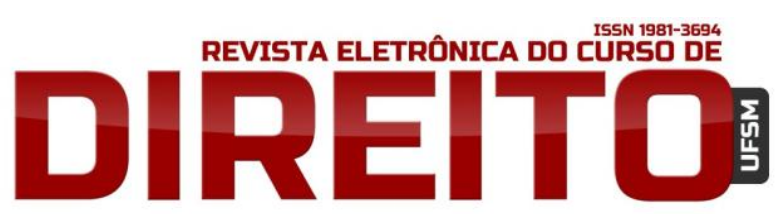

ACADEMIC COLLABORATIONS IN THE AMERICAS: SOME REFLECTIONS ON THE POLITICAL ECONOMY OF LEGAL KNOWLEDGE

DANIEL BONILLA MALDONADO COLIN CRAWFORD

three Central American and one Caribbean country. All of the sessions were delivered in Spanish, the native language of all participants except the Project Director and one U.S.-based instructor. The promised deliverables (the classes and discussions) were completed and so, by that measure, the project was a success.

What we wish to highlight, however, are matters related to the political economy of legal knowledge production involved in such an SNP. The financing for this project came entirely from a U.S. government source. Moreover, the underlying purpose was a commitment to comply with the letter and spirit of a multi-lateral regional trade treaty by increasing the capacity of academics from the region affected by the treaty to respond to some of the consequences of increased trade. This meant that the project was conceived and approved as a vehicle to bring mostly U.S.-based professionals to the region to share their knowledge. This SNP revealed strongly the concepts of subject, time and space. The subject in this SNP were Latin American legal academics, placed in a subordinate position to receive original legal knowledge produced in the U.S.- a not uncommon unilateral knowledge transfer. With respect to time, the SNP project thus underscored the notion of a North-led movement of continual progress in Northerndominated legal knowledge production. In this context, the knowledge produced in the Global North and disseminated in the Global South aimed to promote the objectives of a free trade treaty that had economic prosperity and regional cooperation as central goals, under the guiding hand of the metropolis.

The concept of space as it played out in this SNP exhibited similar characteristics. That is, mostly Global North-based legal experts arrived in Latin American-Global South space with legal knowledge and directed the discussion and form of debate. Moreover, the participation and engagement of the Global South participants affirmed this dynamic imposed by the colonial model of the political economy of legal knowledge. The Global South participants made significant time commitments to arrive and act as recipients of legal knowledge produced in the metropolis, attending a series of 10 one-week seminars lasting over three years. It needs to be remembered, again, that we and other mostly US-based academics were the authors and designers of the project. The point is to acknowledge how even persons who wish to break the dominant models are bound and influenced by them.

In part, some of our dissatisfactions with the ways in which the dominant political economy of legal knowledge imposes itself in SNPs like the project described above drove us to organize more focused events where, we hoped, established personal and professional relations would redirect the tendency to adopt by default the behaviors and practices that characterize 
ISSN 1981-3694

(DOI): $10.5902 / 1981369427197$

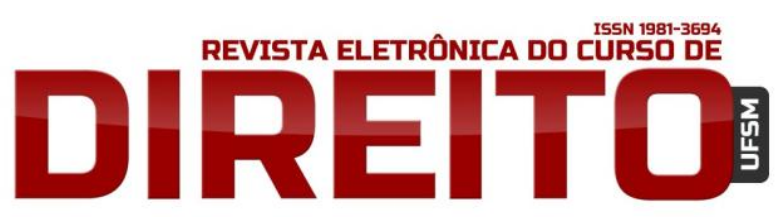

ACADEMIC COLLABORATIONS IN THE AMERICAS: SOME REFLECTIONS ON THE POLITICAL ECONOMY OF LEGAL KNOWLEDGE

DANIEL BONILLA MALDONADO COLIN CRAWFORD

the dominant models. A second type of SNP we designed, a partial response to some of the above concerns, serves to provide the next example to be discussed in this section.

\subsection{SNP 2 - US-Latin American Debate on the Social Function of Property}

This SNP consisted of a semi-closed seminar format with nine participants - six scholars from the U.S., one Colombian and two Brazilians. In this format, organizers concentrated on the physical arrangement of space to permit a focused dialogue. As such, a rectangular table was chosen to promote discussion among participants. It was semi-closed in the sense that the public was allowed to attend and observe, but not to participate. The public consisted mostly of students and the idea was thus that they would benefit from the chance to observe a robust and often disputatious but respectful academic dialogue.

At this event, it was assumed in advance that the working language would be English. Thus, from the start the organizers made a default choice that privileged the universalist values associated with the English language in the dominant models of the political economy of legal knowledge. The event was held in New York and all of the participants spoke fluent English, even though many were from Latin America and the topic, the social function of property, was one with little traction in the U.S. legal academy but that commands extensive attention outside U.S. borders. ${ }^{22}$ This event presented fewer of the concerns noted above in SNP 1. First, all of the participants were trained in the same discipline (law) with a shared interest in a particular legal topic. Second, all participants had a high command of English, the event's default language. Third, the topic of the event was extremely focused so that the participants were all speaking the same academic language. This facilitated enormously a robust and nuanced discussion of the central theme. The participants knew the same literature and many of the global debates and on the issue. As a result, the conference came as close as we have experienced to expressing the meritocratic intellectual aims of the free market of ideas model of the political economy of legal knowledge. All parties were treated as potential agents of the creation and diffusion of legal knowledge (equal subjects), engaged in a reasoned and purposeful debate (not limited in time or considered a priori more or less valuable) and with the objective of sharing legal knowledge that could be replicated freely in different contexts (not limited in space).

\footnotetext{
${ }^{22}$ Namely the "social function of property”. In English, see Duguit, León, 1919. Law in the Modern State.
} 
ISSN 1981-3694

(DOI): $10.5902 / 1981369427197$

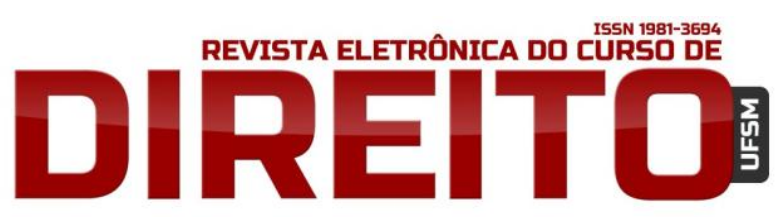

ACADEMIC COLLABORATIONS IN THE AMERICAS: SOME REFLECTIONS ON THE POLITICAL ECONOMY OF LEGAL KNOWLEDGE

DANIEL BONILLA MALDONADO COLIN CRAWFORD

Fourth, the group was assembled by invitation. A South American and a North American law professor equally shared organizational responsibilities. This equality of responsibility expressed the importance of mutuality and transparency that, as indicated, work to recalibrate the often unequal norms of legal knowledge production. In this case, the fact that most participants had a relatively sophisticated understanding of the theme, in combination with the commitment by the organizers to create a respectful if critical tone, helped promote a unique spirit at the event. The organization of the event was guided by the principles of mutual recognition and consensus in the creation and application of the rules directing it. Fifth, most participants submitted paper drafts in advance and participants were asked to read the drafts prior to the event and were each assigned a specific role as a commentator. This process helped maximize understanding and communication amongst participants; there was no hierarchy among the subjects of legal knowledge.

What this example suggests is that focus on and a commitment by organizers to create a platform devoid of subordination (explicit or implicit) is key to fruitful SNPs. Nevertheless, as noted, a default assumption drove the conference: that English would be the language of communication. This occurred largely because of an advance commitment to publish the papers by one of the U.S. university's journals. Consequently, while the event was characterized by fewer of the power imbalances created by the dominant political economy of legal knowledge, the publication process that followed was not free of them.

\subsection{SNP 3 - Discussion of Urban Development, Law and Policy in the Americas}

A third type of SNP presents a longer-term, field-focused seminar format in which we recruited 10-15 mostly junior scholars and senior graduate students to convene in a city and study a theme related to urban development with regard to regional/global social justice, law and policy. We jointly collaborated in a series of five such seminars, each in a different city in the Americas - one in the U.S., one in Central America and three in South America. From the outset, we organized these events with the express purpose of overturning many of the usual assumptions about such seminars. By not insisting on a default model, some of the field seminars evolved both implicitly and explicitly to reject central features of both the free market of ideas and the colonial models of the political economy of legal knowledge. Interestingly, though, this departure from the dominant norm was not always the result of deliberate structuring; it 
ISSN 1981-3694

(DOI): $10.5902 / 1981369427197$

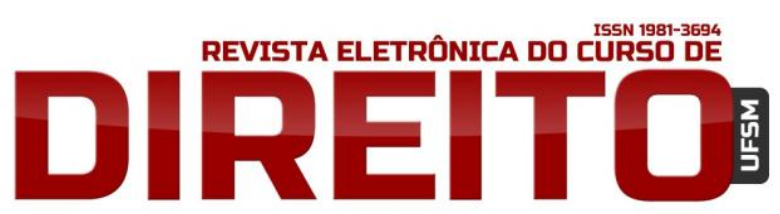

ACADEMIC COLLABORATIONS IN THE AMERICAS: SOME REFLECTIONS ON THE POLITICAL ECONOMY OF LEGAL KNOWLEDGE

DANIEL BONILLA MALDONADO COLIN CRAWFORD

sometimes came about rather unintentionally and sometimes not at all, as will be discussed below.

The seminars in question all lasted a week. Participants were provided with a substantial packet of daily readings (in both English and Spanish or Portuguese) to prepare for each day's session. Each session began with a 60-90 minute academic lecture on the seminar theme, followed by a three-to six-hour field excursion related to the lecture. At the end of the day the entire group would reconvene to reflect upon and discuss the day's activities and events. These discussions were aimed at developing individual research projects and publications that revolved around the seminar theme.

Five such events were held over the course of four years: one in Central America, three in South America, and one in the U.S. The first event in Central America consisted of mostly U.S.-based law professors and law students, was conducted mostly in English with translation as necessary, and demonstrated many successful characteristics of the free market model of the political economy of legal knowledge. As with SNP 2 discussed above, the free market ideal was served by virtue of the fact that all participants were US-based, spoke the same language and shared similar progressive political views. The group arrived to Central America, received information on legal and policy knowledge produced and utilized in Central America, and engaged the speakers in discussion. Thus, with respect to the characteristics of subject, space and time, the parties were equally placed and poised to hold a reasoned, purposeful debate and produce legal knowledge that, at least in theory, could be useful in Latin America and elsewhere.

At the same time, the SNP's execution raised some concerns in terms of the political economy of legal knowledge production. As indicated earlier, the free market model can and often is compromised in some measure by practical concerns, whether organizational, resourcedriven, or both. That was true for the Central American iteration of this SNP, particularly with regard to language. English was the working language for most activities, even though a majority of the US-based participants spoke Spanish. When lectures were delivered by speakers who did not speak English, there was staggered translation. Problems arose, however, on several occasions when the conversation continued in Spanish without translation. The consternation and agitation of some of the English-speaking U.S. professors was palpable, which contrasts markedly with similar situations involving Latin American professionals in the US. In our joint experience of dozens of conferences in English in the US at which Spanish speaking professionals are present with no option for translation, we have never witnessed comparable agitation from 
ISSN 1981-3694

(DOI): $10.5902 / 1981369427197$

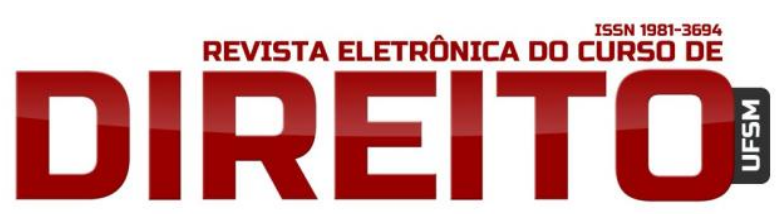

ACADEMIC COLLABORATIONS IN THE AMERICAS: SOME REFLECTIONS ON THE POLITICAL ECONOMY OF LEGAL KNOWLEDGE

DANiEl Bonilla MALDONADO COLIN CRAWFORD

these Latin participants. As indicated above, the colonial model of legal knowledge production privileges one form of communication (English), even when the event takes place in a Global South space.

What might have been the alternative under a different set of practices and habits for the political economy of legal knowledge? An alternative would be to commit to a habit that, prior to engaging a legal culture in the space where it exists, undertook to learn something of the local language on the assumption that no mode of communication can be truly universal and that without such an understanding one cannot deeply grasp the successes, challenges and limitations of any single legal imagination. This is to recognize, as language theory now teaches us, the deep connection between language and cognition ${ }^{23}$. In practice, it would be to commit to a pluralist rather than a universalist principle, acknowledging the subject, time and space limitations of any model of legal knowledge production.

\subsection{SNP 4 - Moot Court in Latin America}

The fourth and final SNP is an international, multi-institutional, student-focused initiative: a Moot Court Competition we developed in collaboration with colleagues from a prominent Brazilian Law School. Moot court competitions are academic activities where groups of law students represent litigants in a simulated trial, with law professors and other legal professionals usually acting as judges. This kind of competition is very common in US law schools, so it must be acknowledged that this effort represented a kind of legal transplant - and a borrowing of a legal education model developed largely in the English-speaking world, a move that is replete with the challenges and implications associated with legal transplants ${ }^{24}$.

Three institutions in different countries with different languages undertook to establish this competition for several reasons. First, because of the success of Moot Court in the US, exporting the concept to Latin America where it has not yet been established seemed to offer a number of opportunities, especially given the increasing importance of multi-national tribunals and the need to develop law students' oral advocacy skills. Second, most such competitions are held outside of Latin America, so developing a Moot Court program that would rotate amongst sponsoring Latin American institutions presented a means for broadening the participant base

\footnotetext{
${ }^{23}$ Lakoff, George and Johnson, Mark. 2003. Metaphors We Live By. Chicago: University of Chicago Press.

24 Graziadei, Michele. 2009. Legal Transplants and the Frontiers of Legal Knowledge. 10 Theoretical Inquiries L. 723.
} 
ISSN 1981-3694

(DOI): $10.5902 / 1981369427197$

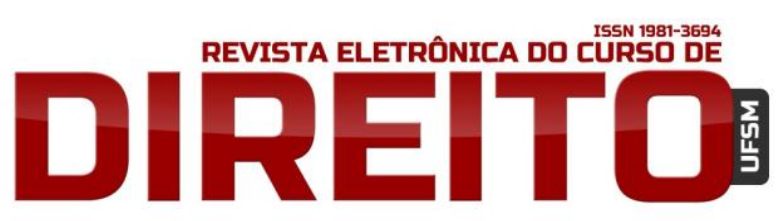

ACADEMIC COLLABORATIONS IN THE AMERICAS: SOME REFLECTIONS ON THE POLITICAL ECONOMY OF LEGAL KNOWLEDGE

DANIEL BONILLA MALDONADO COLIN CRAWFORD

beyond the US. Third, such competitions are mostly held in English, so developing Moot Court in other languages offered another way to broaden institutional and student participation - and on a level playing field. Even Latin American students who have developed strong English-language skills, are generally at a disadvantage when forced to debate in a non-native language; this difficulty is mitigated when students are allowed to write and argue in their native language.

By these measures, the competition was a success. In its first year, 2011, held in Rio de Janeiro, 12 teams competed from three countries and Puerto Rico. In 2015, the event included 21 teams from nine countries (including Germany and India) and Puerto Rico.

Nonetheless, this event faced significant challenges. First, there were financial limitations. In the U.S., team enrollment fees are often $\$ 1,000$ or more. As this would preclude many Latin American teams from participating, we began with far lower fees and more support from the host institutions, though this ultimately presents a challenge to event sustainability. ${ }^{25}$ In addition, the cost of simultaneous translation is high, especially for English-Portuguese, English-Spanish and Portuguese-Spanish professionals. Second, there were differences of legal academic culture to address. For instance, Moot Court in Latin America often includes faculty coaching on input and preparation, while this is almost never the case in the U.S. and this created some tension. Third, styles of argumentation differ by culture, which can foster implicit biases depending on where a competition is held. Argument and oral presentation in the civil law tradition typically begins in a highly formal manner, focusing first upon the legal theory and hierarchy of legal sources that defend a position. By contrast, as noted above, common law training encourages students to be discursive with a propensity to focus on illustrative examples.

The real costs - human and financial - associated with reshaping the political economy of legal knowledge are high, but so are the benefits. The Moot Court event was influenced by the free market of ideas model, yet it was also free of some of this model's weaknesses. Specifically, although the transplanted model came from the North, the shape it took on was one distinctly different. In addition, perhaps because students were writing and arguing in their native languages, they tended to cite opinions and decisions from national and regional courts, which worked in contrast to the traditional intellectual dominance of Global North sources. Holding the events outside the US also appeared to shift the value placed on common-law reasoning and presentation styles. In only one of the four years of the competition did an English-speaking team rank in the top two teams, which effectively served to elevate Spanish

${ }^{25}$ Indeed, the 2016 sponsor, based in the US, canceled the event due to insufficient U.S. enrollments, which the institution had hoped would underwrite the participation of non-U.S. teams. 
and Portuguese to the level of universalizing, collaborative languages in this context and counter the Northern tendency to assign less value to foreign legal sources ${ }^{26}$. This event successfully used collaborative work to reshape the political economy of legal knowledge and its subsequent production.

Of all the SNPs discussed here, this Moot Court experience was perhaps the most balanced in terms of both the politics of the event and its economics, made possible by the collaborators' shared vision and common objectives. This event proved the exception rather than the rule in our experience, in part perhaps because the greater Latin American economic participation ended up dictating working language and performance patterns. Finances, however, were not the only determinant. Shifting language and culture bases also works to upturn traditional notions that the default, "universalist" language should form the basis for legal knowledge creation. Language shapes the way we think and form ideas ${ }^{27}$. To create legal texts for study and argument in one language therefore, inevitably, shapes how concepts are formed. To translate texts for common use and application from their original languages serves to redirect the way legal ideas are framed. This was the objective of the Moot Court in Latin America SNP, and in this sense it was a success.

\section{ANALYTICAL AND PRACTICAL LESSONS LEARNED}

What our experiences in the collaborative academic activities described above revealed to us is the extent to which the dominant models of the political economy of legal knowledge impede the contributions of Latin Americans in the Global South to legal research and dialogue on a global scale. Nonetheless, we have learned that a concerted effort to resist the dominant models of the political economy of legal knowledge can yield results, in at least four respects. First, our experiences suggest that small tactical steps can help slowly to erode the dominance of the models that dominate the legal imagination. Thus, for example, a deliberate preference for a language other than English can slowly help the way people imagine and analyze the law. Not only does such a step represent an explicit rejection of the colonial model. It can also, as

\footnotetext{
${ }^{26}$ Wilson, Matthew J. 2013. Improving the Process: Transnational Litigation and the Application of Private Foreign Law in U.S. Courts. 45 N.Y.U. J. Int'l L. \& Pol. 1111

${ }^{27}$ Boroditsky, Lera. 2009. How Does Our Language Shape the Way We Think?, in Brockman, Max. (ed.). What's Next? Dispatches on the Future of Science. New York: Random House.
} 
we have suggested above, demonstrate that the universalizing and infinite in time features of the free market of ideas model can find expression in different languages.

Second, focused efforts to treat seriously notable creations of legal knowledge outside of the Global North can promote a transfer of knowledge that rejects the usual trade routes. This, we believe, can also help recalibrate the dominant structures and modes of law creation, application and use. To this end, we have therefore worked to draw from relevant Latin American and other Global South examples wherever possible, and by our example to - we hope - prompt others to do so. In our case, this has included discussion of the Mexican concept of "social right" ${ }^{28}$ or the Brazilian notion of the "right to the city" (City Statute 2001) or Colombian contributions that favor the expansion of basic human rights by means of the nation's quite distinctive form of tutela ${ }^{29}$ action $^{30}$. Similarly, we have in our efforts sought to inform others with whom we work of the volume and quality of academic research and publication by centers of investigative strength known to us in Latin America, often far surpassing that of many Global North peers, at universities like the National Autonomous University of Mexico and the University of the Andes in Colombia.

Third, our efforts stressed the need to take law seriously, from the outset, wherever and whenever created. This is to commit to a form of global legal pluralism. Earlier we argued that the dominant models of the political economy of legal knowledge tend to elevate Global North legal production while productions of the Global South are viewed as, variously, products of a parochial or highly localized (and therefore not replicable) political and social culture, or deemed expressions of failed and/or corrupt states ${ }^{31}$. Changing social and political perceptions is, admittedly, not an easy or quick business. Nonetheless, we conclude that an insistence on the potential value of new legal production - from whatever space - as expressions of attempts to

\footnotetext{
${ }^{28}$ Müller, Luis T. Díaz. 1997. “Derechos económicos, sociales y culturales: aportación de México”, Boletín Mexicano de Derecho Comparado 88.

Carroza, Paolo. 2006. "La perspectiva histórica del aporte latinoamericano al concepto de los derechos económicos, sociales y culturales", in Alicia Ely Yamin (ed.), Derechos económicos, sociales y culturales en América Latina: Del inventivo a la herramienta.

${ }^{29}$ The Colombian tutela is a writ (a form of legal request) available to citizens to secure fundamental constitutional rights.

30 Iturralde, Manuel. 2013. Access to constitutional justice in Colombia: opportunities and challenges for social and political change, in Constitutionalism of the Global South: The Three Activist Courts of India, South Africa and Colombia, Cambridge University Press).

${ }^{31}$ Bonilla, Daniel. 2013a. Introduction in Daniel Bonilla (ed)., Constitutionalism of the Global South: The Three Activist Courts of India, South Africa and Colombia, Cambridge University Press).

Esquirol, Jorge L. 2008. The Failed Law of Latin America, 56 Am. J. Comp. L. 75.
} 
ISSN 1981-3694

(DOI): $10.5902 / 1981369427197$

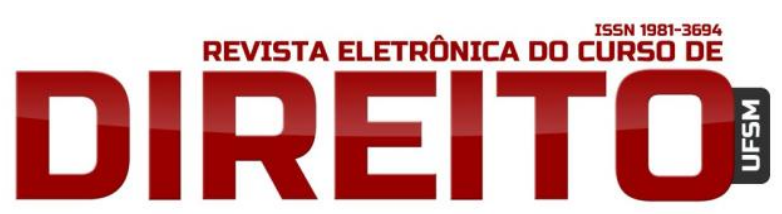

ACADEMIC COLLABORATIONS IN THE AMERICAS: SOME REFLECTIONS ON THE POLITICAL ECONOMY OF LEGAL KNOWLEDGE

DANIEL BONILLA MALDONADO COLIN CRAWFORD

solve the challenges of an evermore connected world is essential, and bears potential benefits in the forms of more analytical and practical tools for all concerned.

Fourth and finally, our experience has shown us the continued importance of adhering to the three principles of successful SNPs we have repeatedly stressed here, namely (1) mutual respect and acknowledgment of difference, (2) an insistence on finding consensus, and (3) a recognition of the need to design activities that balance academic and political aims with differing and often conflicting professional advancement requirements. As indicated above, these principles were not articulated clearly and precisely from the start. Rather, they evolved, representing a rationalization of our practices and political commitments over time. In the process, we worked to pave the way for the construction of an alternative model - or, indeed, of alternative models - of legal knowledge production.

Yet as our narrative above also demonstrates, the political economy of legal knowledge makes it difficult to implement many of the measures just described. As much as one might wish, for example, to shift the default language choice in the recognition that language is not only a tool for communication but composed of structures and modes of thought that can alter the way ideas are conceived ${ }^{32}$, the hard reality is that this is not always practical. Similarly, to describe and recognize legal knowledge innovations and contributions from the Global South may be easier said than done, for at least two reasons. First, if not written in English, there can be serious costs in time and human effort to translate and explain them. Second, the dominant model of legal knowledge production, namely the colonial model, is vertical in structure and by its nature inhibits horizontal exchanges of legal knowledge and legal practices. Small roadblocks can interfere with a concerted effort to shift the dominant models of legal knowledge production and transfer. Gradually, our experience suggests, the careful structuring of new forms of academic collaboration can help shift the contexts in which legal knowledge is created and thus the forms of legal knowledge that are created, applied and used. It is our hope that continued adherence to shared principles, working consciously to try to achieve them as precisely as possible is what has allowed us to work together and with others on academic collaborations in the Americas.

\footnotetext{
${ }^{32}$ Lakoff, George and Johnson, Mark. 2003. Metaphors We Live By. Chicago: University of Chicago Press.
} 


\section{CONCLUSION}

In short, the political economy of legal knowledge dominates the production, circulation and use of legal knowledge. The colonial and free market models of legal ideas control the ways in which the modern liberal imagination describes, analyzes, evaluates and acts with respect to legal knowledge; they do so both explicitly and implicitly. The collaborative academic activities that we have realized during more than ten years were, in part and inevitably, concrete expressions of the models that constitute the dominant political economy of legal knowledge. In part, our activities also demonstrate an effort to escape the centripetal force that these models impose on all of us as individuals.

\section{REFERENCES}

Arocena, Rodrigo, and Judith Sutz. 2005. "Latin American Universities: From an Original Revolution to an Uncertain Transition.” Higher Education 50 (4): 573-592.

Bonilla, Daniel. 2013a. Introduction in Daniel Bonilla (ed)., Constitutionalism of the Global South: The Three Activist Courts of India, South Africa and Colombia, Cambridge University Press).

Bonilla, Daniel. 2013b Legal Clinics in the Global North and South: Between Equality and Subordination, 16 Yale Hum. Rts. \& Dev. L.J. 176.

Bonilla, Daniel. 2015. “La economía política del conocimiento jurídico”, 26 Brazilian Journal of Empirical Legal Studies vol. 2, n. 1.

Boroditsky, Lera. 2009. How Does Our Language Shape the Way We Think?, in Brockman, Max. (ed.). What's Next? Dispatches on the Future of Science. New York: Random House.

Carroza, Paolo. 2006. "La perspectiva histórica del aporte latinoamericano al concepto de los derechos económicos, sociales y culturales", in Alicia Ely Yamin (ed.), Derechos económicos, sociales y culturales en América Latina: Del inventivo a la herramienta.

Centro Agronómico Tropical de Investigación y Enseñanza (CATIE: Center for Tropical Agricultural Research and Education). 2012. Acerca de Nosotros [About Us]. Turrialba, Costa Rica: CATIE. Available online at: http://catieeducacion-

web.sharepoint.com/Pages/aboutus.aspx, accessed on 20 January 2014. 
Centro Agronómico Tropical de Investigación y Enseñanza (CATIE: Center for Tropical Agricultural Research and Education). 2011a. Biennial Report 2010-2011. Turrialba, Costa Rica: CATIE.

Centro Agronómico Tropical de Investigación y Enseñanza (CATIE: Center for Tropical Agricultural Research and Education). 2011b. Iniciativa: Costa Rica País del Conocimiento [Initiative: Costa Rica, Country of Knowledge]. Presentation at Initiative Meeting I, June 28, 2011, Holiday Inn Hotel, Escazu, Costa Rica: CATIE.

Consejo de la Enseñanza Privada Superior [CEPS: Council of Private Higher Education]. 2012. Acerca de CEPS [About CEPS]. Guatemala City, Guatemala: CEPS. Available online at: http://www.ceps.edu.gt, accessed on 20 January 2014.

Culum, Bojana, Roncevic, Nena and Ledic, Jasminka. 2013. “Facing New Expectations. Integrating Third Mission Activities into the University." In The Changing Academy. The Changing Academic Profession in International Perspective, volume 5, edited by Kehm, Barbara M, and Teichler, Ulrich. London, UK: Springer.

Domingo Pilar and Sieder, Rachel (eds.). 2001. Rule of Law in Latin America: The International Promotion of Judicial Reform 1.

Duguit, León, 1919. Law in the Modern State.

Fricker, Miranda. 2007. Epistemic Justice.

EARTH University. 2012. About EARTH. San José, Costa Rica: EARTH University. Available online at: http://www.earth.ac.cr/?lang=en, accessed on 20 January 2014.

Esquirol, Jorge L. 2003. Continuing Fictions of Latin American Law, 55. Fla. L. Rev. 41.

Esquirol, Jorge L. 2008. The Failed Law of Latin America, 56 Am. J. Comp. L. 75.

Esquirol, Jorge L. 2013. Legal Latin Americanism. 16 Yale Hum. Rts. \& Dev. L. J.

Facultad Latinoamericana de Ciencias Sociales Costa Rica [FLACSO: Latin American School of Social Sciences Costa Rica]. 2012. Acerca de... [About ...]. Curridabat, Costa Rica: FLACSO Costa Rica. Available online at: http://www.flacso.or.cr, accessed on 20 January 2014.

Global Higher Education. 2012. Educational Hubs. Cross-Border Education Research Team (CBERT). Albany, NY: State University of New York at Albany. Available online at: http://www.globalhighered.org/edhubs.php, accessed on 20 January 2013.

Gomes, Marcelo and Singer, Helena. 2001 Sociology of Law in Brazil: A Critical Approach, Am. Sociologist, Summer.

Graziadei, Michele. 2009. Legal Transplants and the Frontiers of Legal Knowledge. 10 Theoretical Inquiries L. 723. 
Holm-Nielsen, Lauritz B., Thorn, Kristian, Brunner, José Joaquín, and Balán, Jorge. 2005.

Regional and International Challenges to Higher Education in Latin America. Washington, DC: World Bank.

Huneeus, Alexandra et al. 2010. Introduction in Cultures of Legality: Judicialization and Political Activism in Latin America, Alexandra Hunee, et al., eds., Cambridge University Press.

INCAE Business School. 2012. About Us. Available online at: http://www.incae.edu/en/masterprograms/mba-costa-rica.php, accessed on 20 January 2013.

Huneeus, Alexandra et al. 2012. Centro Latinoamericano para la Competitividad y el Desarrollo Sostenible (CLACDS). Available online at: http://www.incae.edu/es/clacds/, accessed on 20 January 2013.

Iturralde, Manuel. 2013. Access to constitutional justice in Colombia: opportunities and challenges for social and political change, in Constitutionalism of the Global South: The Three Activist Courts of India, South Africa and Colombia, Cambridge University Press).

Kahn Paul. 1999. The Cultural Study of Law.

Knight, Jane. 2011. “Education Hubs: A Fad, a Brand, an Innovation?” Journal of Studies in International Education 15 (3): 221-240.

Kumar Jain, Adishwar. 2011. "Calidad y Acreditación en la Educación Superior en Centroamérica" [Quality and Accreditation in the Higher Education of Central America]. ICAPRevista Centroamericana de Administración Pública [ICAP-Central American Journal of Public Administration] (60-61): 29-57.

Lakoff, George and Johnson, Mark. 2003. Metaphors We Live By. Chicago: University of Chicago Press.

Levy, Daniel C. 1996. Building the Third Sector: Latin America's Private Research Centers and Nonprofit Development. Pittsburgh, PA: University of Pittsburgh Press.

Makau, Mutua. 2000. What is Twail? American Society of International Law, Proceedings of the 94th Annual Meeting.

Mattei, Ugo. 1998. An Opportunity Not to Be Missed: The Future of Comparative Law in The United States, 48 Am. J. Comp. L. 712.

Menski, Werner. 2006. Comparative Law in Global Context, in The Legal Systems of Asia and Africa, Cambridge University Press.

Mickelson, Karin. 2009. Beyond a Politics of the Possible? South-North Relations and Climate Justice, 10 Melbourne J. of Int'l L. 41-423.

Ministerio de Educación [MINED: Ministry of Education]. 2012. Centros Educativos. San Salvador, El Salvador: MINED. Available online at: https://www.mined.gob.sv, accessed on 20 January 2013. 
Ministerio de Educación [MEDUCA: Ministry of Education]. 2012. Centros Educativos [Education Centers]. Panamá: MEDUCA. Available online at: http://www.meduca.gob.pa, accessed on 20 January 2013.

Morris, Rosalind and Spivak, Gayatri. 2010. Can the Subaltern Speak?

Müller, Luis T. Díaz. 1997. "Derechos económicos, sociales y culturales: aportación de México", Boletín Mexicano de Derecho Comparado 88.

Murillo, María Victoria. 2005. "Partisanship Amidst Convergence: The Politics of Labor Reform in Latin America”, 37 Comparative Politics.

Organisation for Economic Cooperation and Development (OECD), Economic Commission for Latin America and the Caribbean (ECLAC). 2011. Latin American Economic Outlook 2012: Transforming the State for Development. Paris: OECD Publishing. Available online at:

http://dx.doi.org/10.1787/leo-2012-en, accessed on 20 January 2013.

OECD. 2012. OECD Family Database. Paris: France: OECD. Available online at:

http://www.oecd.org/social/family/database, accessed on 20 January 2013.

Partnership for Educational Revitalization in the Americas (PREAL). 2007. A Lot to Do: A Report Card on Education in Central America and the Dominican Republic. Washington, DC: PREAL, Task Force on Education Reform in Central America.

Pérez-Perdomo, Rogelio. 2005. Rule of Law and Layers in Latin American, Annals of the American Academy of Political and Social Science.

Reimers, Fernando. 2012. “Innovating Universities." ReVista Harvard Review of Latin America (Fall). Available online at: http://drclas.harvard.edu/publications/revistaonline/fall2012/innovating-universities, accessed on 20 January 2013.

Roy, Alpana. 2008. “Postcolonial Theory and Law: A Critical Introduction”, Adelaide Law Review 29.

Ruskola, Teemu. 2002. Legal Orientalism, 101 Mich. L. Rev. 179-234.

RTN Noticias. 2012. “CATIE Propone a Costa Rica como Destino del Conocimiento" [CATIE Proposes Costa Rica as a Knowledge Destination]. Available online at: http://www.sinart.go.cr, accessed on 20 January 2013.

Rubio F. and Baert P. (Eds.). 2012. The Politics of Knowledge.

Sousa Santos, Boaventura de. 1995. "Three Metaphors for a New Conception of Law: The Frontier, the Baroque and the South”, 29 (4) Law \& Soc'y Rev.569-584.

Stewart, Barry. 1998. Political Economy: A Comparative Approach. Westport: Connecticut and London. 
Svenson, Nanette. 2012. "R\&D in Central America: Panorama and Prospects for International Cooperation." Higher Education 23 (September): 1-16.

Svenson, Nanette, and Montoto, Lisette. 2012. "Universities and the Knowledge Hubs of the Developing World: An in-depth look at the City of Knowledge in the Republic of Panama." Educación Global 16 (63): 53-69.

Thorn, Kristian, and Soo, Maarja. 2006. "Latin American Universities and the Third Mission: Trends, Challenges and Policy Options." World Bank Policy Research Working Paper 4002. Washington, DC: Word Bank. pp. 1-23.

United Nations Development Programme (UNDP). 2012. UNDP human development reports. International human development indicators. http://hdr.undp.org/en/statistics/.

United Nations Educational, Scientific and Cultural Organisation (UNESCO). 2007. The State of Education in Latin America and the Caribbean: Guaranteeing Quality Education for All. Santiago, Chile: UNESCO Regional Bureau of Education for Latin America and the Caribbean.

UNESCO Institute for Statistics. 2012. Data Centre. http://www.uis.unesco.org/

UNESCO International Institute for Higher Education in Latin America and the Caribbean (UNESCO-IESALC). 2010. La Universidad Latinoamercana en Discusión [Discussion of the Latin American University]. Caracas, Venezuela: UNESCO-IESALC.

Universidad del Valle de Guatemala [University of the Valley of Guatemala]. 2012. Investigación. Guatemala City, Guatemala: University of the Valley of Guatemala. Available online at: http://www.uvg.edu.gt, accessed on 20 January 2013.

Universidad para la Paz (UPEACE) [University for Peace]. 2012. About UPEACE. Ciudad Colón, Costa Rica: UPEACE. Available online at: http://www.upeace.org/about/, accessed on 20 January 2013.

UPEACE. 2011. The Hon. Ruth Dreifuss at UPEACE. UPEACE News Flash (October 11). Available online at: http://www.upeace.org/news/newsflash/2011/NFOctober2011.pdf, accessed on 20 January 2013.

Wilson, Matthew J. 2013. Improving the Process: Transnational Litigation and the Application of Private Foreign Law in U.S. Courts. 45 N.Y.U. J. Int'l L. \& Pol. 1111

World Bank. 2005. Central American Education Strategy: An Agenda for Action. Washington, DC: World Bank.

World Bank. 2012a. Data-World development indicators. Washington, DC: World Bank. Available online at: http://data.worldbank.org/indicator, accessed on 20 January 2013.

World Bank. 2012b. Worldwide governance indicators. Government Effectiveness. Washington, DC: World Bank. Available online at: http://info.worldbank.org/governance/wgi/index.asp, accessed on 20 January 2013. 
ISSN 1981-3694

(DOI): $10.5902 / 1981369427197$

REVISTA ELETRÔNICA DO CURSO DE

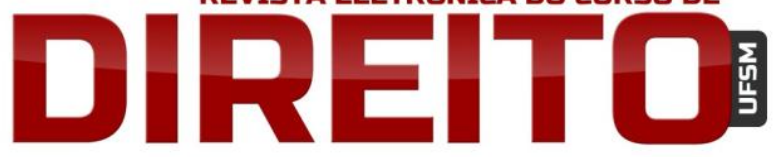

ACADEMIC COLLABORATIONS IN THE AMERICAS: SOME REFLECTIONS ON THE POLITICAL ECONOMY OF LEGAL KNOWLEDGE

DANiEL Bonilla MALDONADO COLIN CRAWFORD

Zaglul, Jose, and Sherrard, Daniel. 2005. "Higher Education in Economic Transformation.” In Going for Growth: Science, Technology and Innovation in Africa, edited by Calestous Juma (pp. 34-44). London, UK: The Smith Institute.

Zamorano. 2012. Explore Zamorano. http://www.zamorano.edu/english/, accessed on 20 January 2013.

Artigo Convidado / Invited Article.

COMO CITAR O ARTIGO (ABNT) / HOW TO CITE THE ARTICLE (ABNT/BRAZIL)

BONILLA MALDONADO, Daniel; CRAWFORD, Colin. ACADEMIC COLLABORATIONS IN THE AMERICAS: SOME REFLECTIONS ON THE POLITICAL ECONOMY OF LEGAL KNOWLEDGE. Revista Eletrônica do Curso de Direito da UFSM, Santa Maria, RS, v. 12, n. 2 , p. 648-674, ago. 2017. ISSN 1981-3694. Disponível em: <https://periodicos.ufsm.br/revistadireito/article/view/27197>. Acesso em: dia mês. ano. doi:http://dx.doi.org/10.5902/1981369427197. 